\title{
Sensory Evaluation and Chemical Characteristics of Smoked Stingray (Dasyatis Blekeery) Processed by Using Two Different Liquid Smoke
}

\author{
Fronthea Swastawati, Eko Susanto, Bambang Cahyono, and Wahyu Aji Trilaksono
}

\begin{abstract}
The purpose of this research was to determine the quality of smoked stingray (Dasyatis blekery). The fish were divided into two groups; then processed using corncob (CCLS) and coconut shells (CSLS) liquid smoke. All of smoked stingray samples were subjected to sensory and chemical analysis. Sensory analysis on both samples was no statistically different. On the other hand, the lysine availability was different either in the in the raw materials or smoked samples due to smoking process and duration of storage. Different liquid smoke and storage time gave significant effect to lysine availabilty $(p<0,05)$. Both liquid smoke gave significant effect $(\mathrm{p}<0,05)$ to $\mathrm{PV}(\mathrm{CSLS}=2,816 \mathrm{meq} / \mathrm{kg} \&$ CCLS $=2,195 \mathrm{meq} / \mathrm{kg})$ and TBA (CSLS $=109,685 \mathrm{mg}$ malonaldehide $/ \mathrm{kg} \&$ CCLS = $45,169 \mathrm{mg}$ malonaldehide/ $\mathrm{kg}$ ), but during storage this value were decrease as an effect of antioxidant activities of phenolic compounds consist in each liquid smoke. In contrast, pH values were increase. Both liquid smoke were able to apllied as a method of smoking fish.
\end{abstract}

Index Terms-Chemical characteristic, coconut shells liquid smoke, corn cob liquid smoke, sensory, stingray.

\section{INTRODUCTION}

Smoking method mostly imparts a desirable flavour and inhibit the growth of microbe. One methods that becoming popular nowadays is the use of liquid smoke. Liquid smoke has some advantages such as they are easily to applied, the concentration of liquid smoke can be controlled, resulted uniformity products and less taxing on the environment [1]. In related to consumer preferences, it is indicated that consumers do not like the same kind of products. For example some people require a strong smoke odour and flavour, others want a specific "wood" or smoke materials" [2], [3].

The possible materials used in the production of liquid smoke in Indonesia are corncob and coconut shells, due to their specific characteristics in chemical compound. Stingray is one of the most acceptable and popular fish species to be smoked in Indonesia especially processed by traditional method. Accurate shelf life information convinces consumers and improves the quality of product [4]. The objective of this research was to determine the effects of two different liquid smoke flavourings on the sensory and chemical characteristics of stingray during

Manuscript received April 21, 2012; revised May 22, 2012.

The authors are with Department of Fisheries, Faculty of Fisheries and Marine Science, Diponegoro University, Jl. Prof. Soedarto, SH, Kampus Undip Tembalang Semarang 50275 Indonesia (e-mail: fronthea_thp@yahoo.com). storage at ambient temperature.

\section{MATERIALS AND METHODS}

\section{A. Production of Liquid Smoke Flavouring}

The Corncob were collected in Grobogan Regency $( \pm 30$ $\mathrm{Km}$ from Semarang, Cenral Java) and coconut shell were collected in around Semarang City. They were air dried for several hours prior to process. The pyrolysis process was started with smoke generator controlled heating. The temperature was measured with a thermostat positioned in the centre of the reactor; the maximum temperature reached was $250^{\circ} \mathrm{C}$. The production was stopped when the smoke materials was totally pyrolysed. The liquid smoke resulting from the process was filtered through a paper filter and collected in some bottles.

\section{B. Smoking Process}

A total of $9 \mathrm{~kg}$ of stingray collected from Semarang fish market were used in this experiment. Reference [5], shows the procedure of smoking process. The fish were eviscerated, being cut and washed thoroughly, and then divided into two groups. One group was subjected to CCLS while the other was treated by CSLS. The fish then dipped into $7.5 \%$ of salt and $5 \%$ of liquid smoke solution for 15 minutes. The cured fish were placed into an oven and cooked at three stages of temperatures $40-50^{\circ} \mathrm{C}$ for 1 hour; $50-60^{\circ} \mathrm{C}$ for 1 hour and $60-80^{\circ} \mathrm{C}$ for 2 hours. The part from each smoked fish steak was removed and put into polypropylene bags, stored at room temperature $\left(31 \pm 1{ }^{\circ} \mathrm{C}\right)$ and used for laboratory analysis.

\section{Laboratory Analysis}

In order to evaluate quality characteristic of liquid smoke and smoked fish some chemical analysis i.e : hydrocarbon components, sensory analysis, proximate (SNI 01-23542006), pH, Thiobarbituric acid, lysine and PV were investigated [6].

\section{1) Proximate Analysis}

\section{a) Moisture}

Fish samples were dried by using an oven for \pm 24 hours at $100^{\circ} \pm 5^{\circ} \mathrm{C}$ until the weight of samples remained constant. The percentage of moisture content was calculated based on dry weight /wet weight and multiplied by $100 \%$.

\section{b) Crude Protein}

Protein content were determined by using Kjeldahl Method. Protein content formula are as follows : 


$$
\% \mathrm{~N}=\frac{\mathrm{ml} \mathrm{HCl} \times \mathrm{N} \mathrm{HCl} \times 14,008}{\text { mg of sample }} \times 100 \%
$$

$\%$ protein $=\% \mathrm{~N} \times 6,25$

Note:

N HC: Normality of standart $\mathrm{HCl}(0,02 \mathrm{~N})$

ml $\mathrm{HCl}$ : Standart volume $\mathrm{HCl}$ for titration

14,008: Weight from nitrogen atom

6,25 : Amount of nitrogen base in fish protein

c) Lipid

Determination of lipid content used was Soxhlet method, where the principle lipid separation from material was using organic solvent chloroform. Lipid which have extraction in flask flowing $\mathrm{N}_{2}$ for the purpose to evaporate organic solvent in flask. After this the flask can weigheing and calculate the procentage of lipid content. Here is the formula to calculated of lipid content :

$$
\frac{\text { gr sample }- \text { gr of sample before extraction }}{\text { gr of sample with flask after extraction }} \times 100 \%
$$

\section{2) $A s h$}

Principle method for determination of ash content is oxidation all of organic materials and calculating the last ash with gravimetric methode :

$$
\frac{\text { ash content }(w b)}{(100-\text { water content })} \times 100 \%
$$

\section{Lysine Availibilty}

Weigheing 1-2 gr sample to be homogenized with 100 $\mathrm{mL}$ aquadest. Take $10 \mathrm{~mL}$ homogenated sample and diluted with $100 \mathrm{~mL}$ aquadest and homogenize. From the dilution 1 $\mathrm{mL}$ was taken then to fill into tube which $2 \mathrm{~mL}$ reagent metilen glikol monometil ester added and then heated for 20 minutes. Calculated absorbing colour with spectrofotometers until wave lenght reach to $570 \mathrm{~nm}$.

\section{E. $P V$}

$500 \mathrm{mg}$ of methanol extract filling into 250 $\mathrm{ml}$ Erlenmeyer was then added $30 \mathrm{ml}$ mixture of acetic acid : chloroform : ethanol (4:9:5), and 1 gram of potassium iodide (KI). Save as in dark place for 30 minutes. After that added to $30 \mathrm{ml}$ of distilled water and starch solution. Furthermore the result titrated with $0.02 \mathrm{~N}$ sodium thiosulfate, until the blue color disappeared. The amount (ml) solution Natiosulfat recorded.

\section{F. Thiobarbituric Acid}

5 grams of sampel were weighed and homogenize with $50 \mathrm{~mL}$ aquadest. Filling into tube destilation and were added 2,5 $\mathrm{mL} 4 \mathrm{~N} \mathrm{HCl}$ until reached $\mathrm{pH} 1,5$. They were heated for 10 menit until reach $50 \mathrm{~mL}$ destilate. Mixing the destilate then filtrating and replace $5 \mathrm{~mL}$ into closed erlenmeyer $50 \mathrm{~mL}$. Then added with $5 \mathrm{~mL}$ TBA reagent and heated for 35 minutes, cooled the tube to measuring they absorbance in wave lenght $528 \mathrm{~nm}$ and finally calculate TBA value with number of TBA $(7,8 \mathrm{D})$.

\section{G. $P H$}

$20 \mathrm{~mL}$ of liquid smoke samples were put into a glass beaker. Then the $\mathrm{pH}$ meter sensor was put into liquid smoke sample and $\mathrm{pH}$ value was recorded when the reading was constant (Manual Procedure of SUNTEX SP-701 pH meter).

\section{H. Statistical Analysis}

The collected data from two replications was subjected to a $t$-test to determine the differences between corncob liquid smoke and coconut shells liquid smoke (independent variable) for each parameter using the SPSS 11. Significantly different treatment means were further separated using the Least Significant Differences method and significance was reported at $p<0.05$ with means \pm deviation standard.

\section{RESULTS AND DISCUSSION}

\section{A. Sensory Characteristic During Storage}

In general, smoked stingray treated by CCLS received slightly higher sensory scores of than CSLS treatment. These indicates that the colour of smoked fish was caused by the decomposition of carbonyl amino and it has correlated with the decrease in carbonyl group during storage. Phenol is substances that play an important role in the desirable characteristic of flavor and odour on smoked fish [7]-[8]. Taking only sensory qualities into account, the samples were rejected by the panelist when they showed characteristic of softening, low elasticity, firmless, discolouration and low brightness. All samples were rejected at 4 days of storage in room temperature.

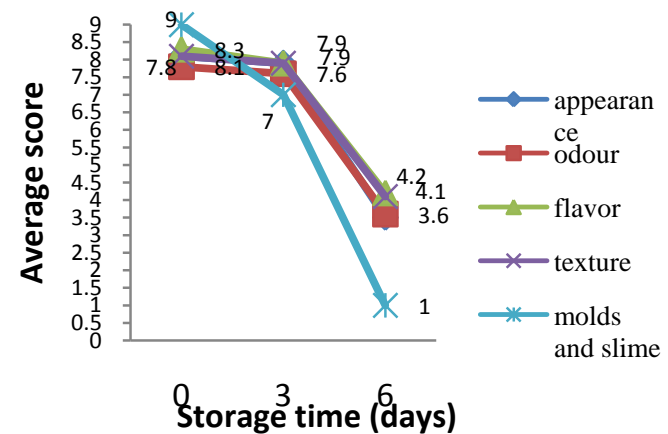

Fig. 1. (a) Average score of smoked stingray sensory with CCLS

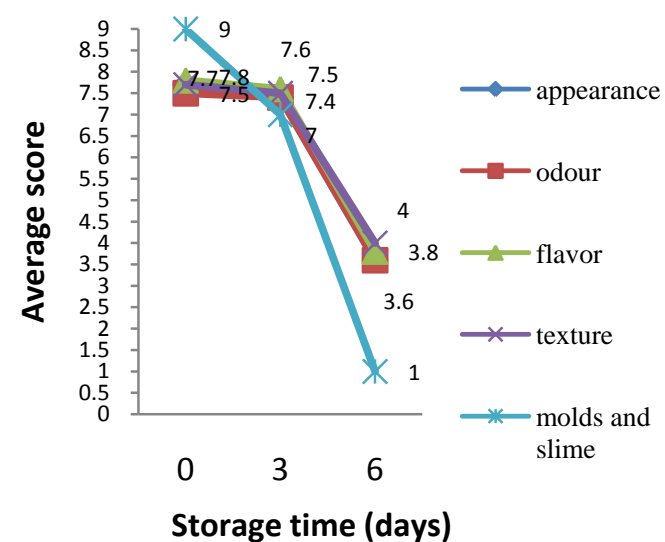

Fig. 1. (b) Average score of smoked stingray sensory with CSLS

\section{B. Liquid Smoke Characteristics}

Both CCLS and CSLS, have some similarities and differences characteristics (see Table I). Major component found in CCLS were dominated by three compound namely propanoic acid, 2 furan methanol and phenol. Meanwhile, CSLS were dominated by phenol,2-methoxy; phenol,2,6,dimethoxy; and pyrazole,1,4-dimethyl. 
International Journal of Bioscience, Biochemistry and Bioinformatics, Vol. 2, No. 3, May 2012

TABLE I: Percentage of Major CARbonyl DeRIVATIVES IN CCLS AND CSLS

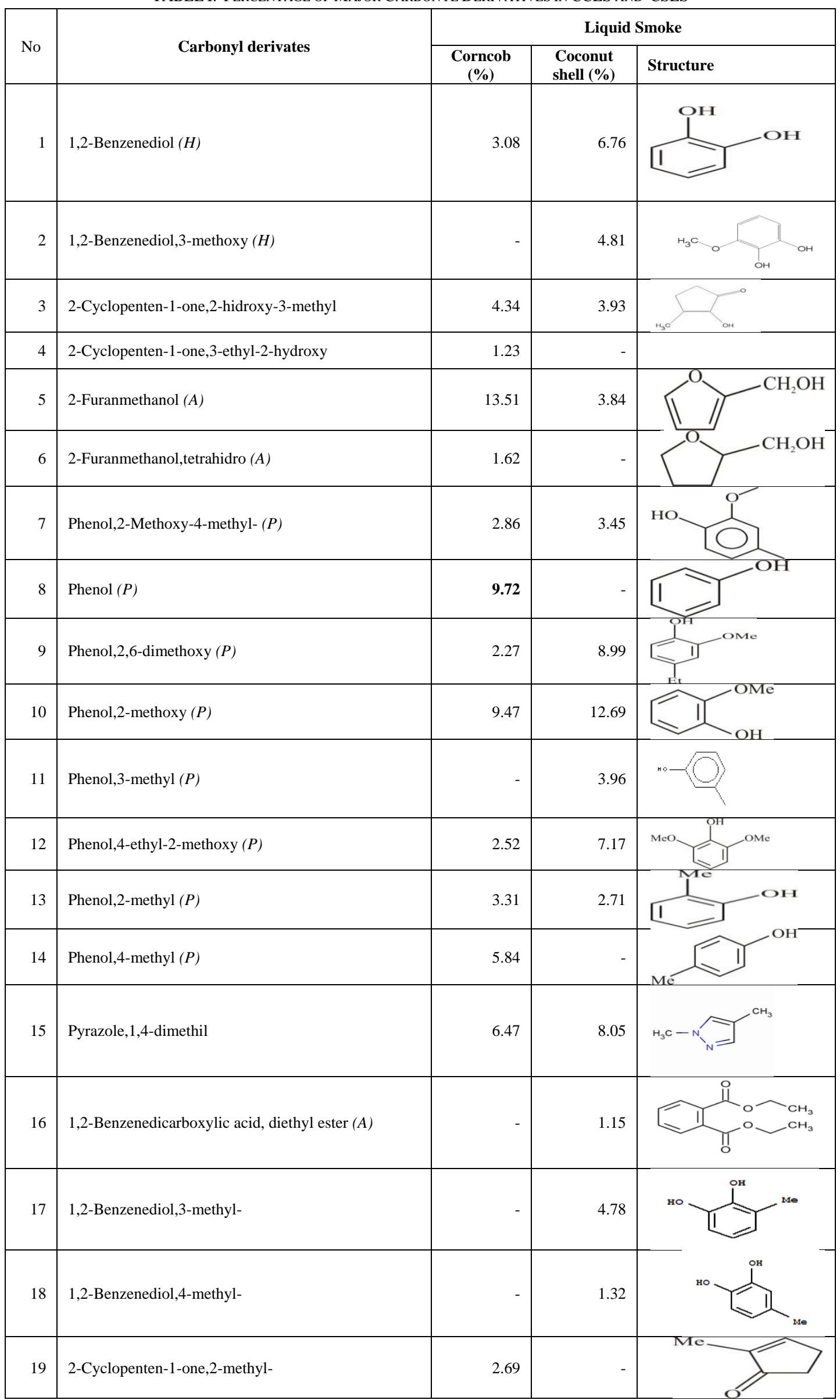




\begin{tabular}{|c|c|c|c|c|}
\hline 22 & 4-Methoxy-3-(methoxymethyl)phenol & - & 5.08 & \\
\hline 23 & Hexadecanoic acid $(a)$ & 0.9 & 0.71 & \\
\hline 24 & Propanoic acid $(a)$ & 17.53 & - & \\
\hline 25 & Silanamine, N-phenil- & ـ & 1.21 & \\
\hline 26 & 2H-Pyran-2-one,4,6-dimethyl- & 3.05 & - & \\
\hline 27 & 3-Butene-1,2-diol & 5.3 & - & $\mathrm{H}_{2} \mathrm{C} \mathrm{CHCH}(\mathrm{OH}) \mathrm{CH}_{2} \mathrm{OH}$ \\
\hline 28 & Urea & 1.62 & - & $\mathrm{H}_{2} \mathrm{NCONH}_{2}$ \\
\hline
\end{tabular}

Major component found in CCLS were dominated by three compound namely Propanoic acid, 2 furan methanol and phenol. Meanwhile, CSLS were dominated by phenol,2-methoxy; phenol,2,6,-dimethoxy; and pyrazole,1,4-dimethyl. Reference [9] reported that thyme liquid smoke were contained the main components of 2furancarboxaldehyde; 2-furanmethanol;3-methyl-1,2cyclopentanedione; 1-acetoxy-propan-2-one and 3-methyl2-butanone.

Total phenol derivatives formed from the thermal degradation of lignin are also present and in general contribute with typical smoky notes. These fraction are important for their attributed antioxidant activity. The global phenolic derivatives found in CCLS were lower than that of CSLS.

\section{Chemical Characteristic during Storage Proximate}

The results of proximate analysis on raw materials and smoked fish showed variation on chemical composition (Table II). It was indicated that the changes on proximate composition of smoked fish was affected by the chemical compound of liquid smoke.

\begin{tabular}{|c|c|c|c|c|}
\hline Stingray & $\begin{array}{c}\text { Moisture } \\
(\%)\end{array}$ & $\begin{array}{c}\text { Crude } \\
\text { Protein } \\
(\%)\end{array}$ & $\begin{array}{c}\text { Lipid } \\
(\%)\end{array}$ & $\begin{array}{l}\text { Ash } \\
(\%)\end{array}$ \\
\hline Raw & $73,78 \pm 0,06$ & $\begin{array}{l}21,00 \pm \\
0,21\end{array}$ & $\begin{array}{l}2,40 \pm \\
0,37\end{array}$ & $\begin{array}{l}1,44 \pm \\
0,40\end{array}$ \\
\hline
\end{tabular}

\begin{tabular}{|c|c|c|c|c|}
\hline $\begin{array}{l}\text { Coconut } \\
\text { shells } \\
\text { liquid } \\
\text { smoke }\end{array}$ & $61,47 \pm 0,33$ & $\begin{array}{l}33,73 \pm \\
0,04\end{array}$ & $\begin{array}{l}1,84 \pm \\
0,26\end{array}$ & $\begin{array}{l}3,58 \pm \\
0,36\end{array}$ \\
\hline $\begin{array}{l}\text { Corn cob } \\
\text { liquid } \\
\text { smoke }\end{array}$ & $66,50 \pm 0,63$ & $\begin{array}{l}32,54 \pm \\
0,09\end{array}$ & $\begin{array}{l}2,06 \pm \\
0,08\end{array}$ & $\begin{array}{l}2,860 \\
\pm 0,37\end{array}$ \\
\hline
\end{tabular}

The lower of moisture, the higher crude protein and lipid of smoked fish. It's becaused heating processed could reducing moisture which can give some effect like denaturation of protein and suspended minerals. Reference [1] showed that lipid fresh salmon about 15,33\% - 16,63\% after smoked could be $15,12 \%-16,58 \%$.

\section{1) Lysine}

The lysine content on raw material and smoked fish can see in (Table III)

TABLE III: THE EFFECT OF ROOM TEMPERATURE STORAGE ON AVAILABLE OF LYSINE IN SMOKED STINGRAY

\begin{tabular}{llll}
\hline \multirow{2}{*}{ Stingray } & \multicolumn{3}{c}{ Storage Time (Days) } \\
\cline { 2 - 4 } & \multicolumn{1}{c}{0} & \multicolumn{1}{c}{3} & \multicolumn{1}{c}{6} \\
\hline Coconut shells & $1,38 \pm$ & $1,35 \pm$ & $0,87 \pm$ \\
liquid smoke & 0,42 & 0,01 & 0,00 \\
Corn cob liquid & $1,65 \pm$ & $1,10 \pm$ & $0,41 \pm$ \\
smoke & 0,00 & 0,01 & 0,00 \\
\hline \multicolumn{2}{l}{ Note: Value + standar deviation }
\end{tabular}

TABLE IV: THE EFFECT OF ROOM TEMPERATURE STORAGE ON THIOBARBITURIC ACID (TBA), PH, AND PEROXIDE VALUE

\begin{tabular}{|l|l|l|l|}
\hline \multirow{2}{*}{ Stingray } & \multicolumn{3}{c|}{ Storage Time (Days) } \\
\cline { 2 - 4 } & \multicolumn{1}{|c|}{0} & \multicolumn{1}{c|}{3} & 6 \\
\hline \multicolumn{3}{|c|}{ Coconut shells liquid smoke } \\
\hline Peroxide value & $2,82 \pm$ & $2,20 \pm$ & $0,82 \pm$ \\
(miliequivalent/kg) & 2,20 & 0,04 & 0,00 \\
\hline TBA (mg & $109,69 \pm$ & $37,14 \pm$ & $15,48 \pm$ \\
malonaldehide/kg) & 0,36 & 1,58 & 0,36 \\
\hline \multirow{3}{*}{ pH } & $7,30 \pm$ & $8,30 \pm$ & $8,30 \pm$ \\
& 0,00 & 0,00 & 0,00 \\
\hline \multicolumn{4}{|c|}{ Corn cob liquid smoke } \\
\hline Peroxide value & $2,20 \pm$ & $7,49 \pm$ & $5,45 \pm$ \\
(miliequivalent/kg) & 0,03 & 0,07 & 0,05 \\
\hline TBA (mg & $45,17 \pm$ & $18,79 \pm$ & $42,01 \pm$ \\
malonaldehide/kg) & 0,77 & 0,47 & 0,42 \\
\hline \multirow{2}{|c|}{ pH } & $8,20 \pm$ & $8,50 \pm$ & $8,20 \pm$ \\
\hline
\end{tabular}

On raw material, The lysine content of fresh stingray was 0,28 . They were then increased as an effect of smoking process but gradually decreased during storage. Changes in lysine can be caused in part by the Maillard reaction [1]. In addition, the crooslinking of the heated protein caused the reaction on lysine with other component on food [3]. Storage time gave statistically significant effect $(\mathrm{p}<0,05)$ on lysine availability of both samples. Reference [7] reported a loss of $12,2 \%$ of lysine in smoked fish in the cold air for 2 days.

\section{2) $P V, T B A$ and $p H$}

The results showed that peroxide values tends to decrease during storage. 
The slow rate of oxidation during storage might be due to the effectiveness of the smoke antioxidants [1]. Similarly, Peroxide value correlates well with sensory analysis of rancidity [10]. Smoking process can influence on lipid oxidation as the function of phenolic compounds [1].

The results showed that TBA values on smoked fish vary during storage. They were large ranging from 109,685 to 15,481 at the end of storage. During storage, TBA values were significantly decreased. Generally, $\mathrm{pH}$ value on smoked fish increased during storage time. During post mortem changes, $\mathrm{pH}$ is more or less constant or slightly increased due to the formation of basic compounds [10].

\section{CONCLUSION}

The two liquid smoke flavourings studied led to changes in the characteristic of smoked stingray. Sensory characteristic changes were similar in both corncob and coconut shells liquid smoke treatment. In contrast, chemical changes on smoked stingray were different. Although each liquid smoke has specific chemical compounds but they could be used to smoked stingray.

\section{ACKNOWLEDGEMENT}

This project is funded by Central Java Educational Agency in 2009 and Directorate General of Higher Education, Indonesia Ministry of National Education in 2006 - 2007. The author would like to thank Ajar Tungga Kumara for helping this project.

\section{REFERENCES}

[1] I. Kolodziejska, C. Niecikowska, E. Z. Sikorski, and A. Kolakowska, "Lipid oxidation and lysine availability in Atlantic mackerel hot smoked in mild condition," Bulletin of the Sea Fisheries Institute, vol. 161, pp. 15 - 27. 2004

[2] Z. Sikorski, N. Haard, T. Motohiro, and S. P. Bonnie, Quality In P. E. Doe (Ed.), Fish Drying and Smoking, Production and Quality, Lancaster Basel: Technomic publishing, pp. 89 - 94, 1998.

[3] S. E. Fayle, J. A. Gerard, L. Simmons, S. J. Meade, E. A. Reid, and A. C. Johnston, "Crosslinking of proteins by dehydroascorbic acid and its degradation products," Food Chemistry, vol. 70, pp. 193-198. 2000.

[4] Quality Standard of Smoked Fish, Indonesian National Standard. National Standaritation Agency. SNI no. 01-2356-2006, Standar mutu ikan asap, Standar Nasional Indonesia, Badan Standarisasi Nasional. SNI no. 01-2356-2006.

[5] O. Martinez, J. Salmerón, M. D. Guillén, and C. Casas, “Textural and physicochemical changes in salmon (Salmo salar) treated with commercial liquid smoke flavourings," Food Chemistry, vol. 100, pp. 498-503, 2007.

[6] Chemical Analysis of Fisheries Product. Indonesian National Standard (SNI), National Standaritation Agency, Standar Nasional Indonesia, Analisa Kimiawi Produk-Produk Perikanan, Badan Standarisasi Nasional, 1991.

[7] J. P. G. Irard, Smoking, Technology of Meat and Meat Products (translated by Bernard Hemmings and A.T.T, Clermont-Ferrand), Ellis Horwood, New York, 1992.

[8] M. Cardinal, J. Cornet, T. Sérot, R. Baron, "Effects of the smoking process on odour characteristics of smoked herring (Clupea harengus) and relationships with phenolic compound content," Food Chemistry, pp. 137-146. 2006

[9] M. D. Guillen and M. J. Manzanos, "Smoke and liquid smoke. Study of an aqueous smoke flavouring from the aromatic plant Thymus vulgaris L," Journal of the Science of Food and Agriculture, vol. 79, pp. 1267-1274. 1999.

[10] H. H. Huss, Fresh Fish-quality and Quality Changes, FAO. Rome, 1995. 